\title{
Analisis Interaksi Obat Penyakit Ginjal Kronik di RSUD Prof. Dr. W. Z. Johannes Kupang
}

\author{
Maria Philomena Erika Rengga, Ridwan Brampi Kono, dan Christin Aprillian Beama
}

Program Studi Sarjana Farmasi, Fakultas Kesehatan, Universitas Citra Bangsa, Kupang, Indonesia

Korespondensi: Maria Philomena Erika Rengga

Email: rilkerengga@ucb.ac.id

Submitted : 03-12-2021, Revised : 22-05-2021, Accepted : 24-06-2021

\begin{abstract}
ABSTRAK: Interaksi obat penting untuk diperhatikan, dicegah, dan ditangani karena dapat mempengaruhi kerja dari obat dengan mengubah kadar obat dalam darah, meningkatkan risiko efek samping atau toksisitas obat, dan dapat memperparah kondisi medis tertentu yang dimiliki pasien, termasuk Penyakit Ginjal Kronik (PGK). Masalah interaksi obat akibat polifarmasi pada pasien dengan PGK menjadi penting karena efek dari interaksi obat dapat mempengaruhi keberhasilan terapi, padahal PGK sendiri merupakan kondisi dengan berbagai komorbid yang harus dikontrol. RSUD Prof. Dr. W. Z. Johannes sebagai satu-satunya RS rujukan pemerintah tingkat provinsi di Nusa Tenggara Timur membutuhkan data deskriptif interaksi obat PGK agar dapat dilakukan langkah perbaikan ke depannya. Tujuan penelitian ini adalah untuk menggambarkan interaksi obat PGK di RSUD Prof. Dr. W. Z. Johannes tahun 2018. Penelitian ini merupakan penelitian deskriptif kuantitatif yang pengambilan datanya dilakukan secara retrospektif. Teknik systematic sampling digunakan untuk memilih 100 sampel dari 400 populasi PGK. Selanjutnya 16 sampel dieksklusi sehingga hanya 84 sampel yang dianalisis. Interaksi obat secara potensial ditemukan pada 72 pasien $(85,7 \%)$ dan tertinggi pada tingkat keparahan sedang $(68,0 \%)$. Interaksi obat paling banyak berpotensi terjadi antara furosemid dan golongan Angiotensin Converting Enzyme-inhibitor.
\end{abstract}

Kata kunci: interaksi obat; masalah terkait obat; Penyakit Ginjal Kronik; tingkat keparahan

\begin{abstract}
Drug interactions are important to be identified, prevented, and treated because they may affect the action of drug levels in the blood, increase the risk of side effects or drug toxicity, and may aggravate certain medical conditions, including Chronic Kidney Disease (CKD). The problem of drug interactions due to polypharmacy in patients with CKD is important because it may affect the outcomes of therapy, while CKD itself is a condition with various comorbidities that must be controlled. RSUD Prof. Dr. W. Z. Johannes as the only provincial government referral hospital in East Nusa Tenggara needs descriptive data on CKD drug interactions so that corrective and improvement plans can be taken in the future. This research was done to determine the potential drug interactions in hospitalized CKD patients in RSUD Prof. Dr. W. Z. Johannes in 2018. This was a descriptive quantitative study and the data collection was conducted retrospectively. One hundred samples were selected from a total of 400 population using systematic sampling technique. Furthermore, 16 samples were excluded so the samples used were 84 samples. Potential drug interactions were found in 72 patients (85.7\%) and moderate severity of drug interaction was the highest among it (68.0\%). The highest potential drug interaction was between furosemide and Angiotensin Converting Enzyme-inhibitor.
\end{abstract}

Keywords: Chronic Kidney Disease; drug interactions; Drug Related Problem; severity of drug interactions 


\section{Pendahuluan}

Interaksi obat penting untuk diperhatikan, dicegah, dan ditangani karena dapat mempengaruhi kerja dari obat dengan mengubah kadar obat dalam darah, meningkatkan risiko efek samping atau toksisitas obat, dan dapat memperparah kondisi medis tertentu yang dimiliki pasien. Interaksi obat dapat terjadi pada berbagai kelompok usia, namun frekuensi polifarmasi pada pasien dengan penyakit kronis atau lanjut usia, umumnya meningkatkan risiko kejadiannya [1]. Penyakit Ginjal Kronik (PGK) sebagai salah satu penyakit yang timbul akibat berbagai penyakit komorbid, tidak lepas dari masalah interaksi obat. PGK didefinisikan sebagai gangguan pada struktur maupun fungsi ginjal, yang terjadi paling tidak selama 3 bulan dengan implikasi pada kesehatan [2]. Identifikasi interaksi obat PGK sejak dini dapat menurunkan bahkan mencegah dampak negatif pada keberhasilan terapi.

Pasien dengan PGK seperti telah diuraikan sebelumnya, biasanya mengalami sejumlah komorbiditas termasuk penyakit yang mendasari terjadinya PGK, yang mayoritas adalah hipertensi dan diabetes melitus. Adanya penyakit komorbid mengakibatkan pasien dengan CKD berisiko tinggi mengalami interaksi obat karena mendapatkan kelas terapi obat yang berbeda-beda $[3,4]$. Interaksi obat dapat meningkatkan morbiditas dan mortalitas, oleh karena itu identifikasi dini dari kandungan aktif obat, pengaruhnya terhadap efek terapi, dan signifikansi klinisnya sangat bermanfaat bagi pasien PGK. Interaksi obat diklasifikasikan berdasarkan tingkat keparahannya menjadi berat, sedang, dan ringan. Interaksi berat membutuhkan alternatif terapi karena berbahaya jika diberikan bersama, interaksi sedang dapat diberikan bersama tetapi membutuhkan pemantauan yang ketat, dan interaksi ringan tidak signifikan karena hanya mempunyai efek yang kecil dan tidak berbahaya [5].

Melalui penelitian ini diharapkan dapat meningkatkan kewaspadaan serta pengetahuan tenaga kesehatan, khususnya dokter sebagai penulis resep dan apoteker dalam hal ini farmasis klinis, mengenai interaksi obat pasien PGK. Dengan peningkatan pengetahuan, interaksi obat yang tidak dikehendaki (seperti interaksi berat dan sedang) dapat dihindari [5]. RSUD Prof. Dr. W. Z. Johannes merupakan satu-satunya RS pemerintah rujukan provinsi di Nusa Tenggara Timur, yang berlokasi di kota Kupang. Sejauh ini diketahui belum pernah dilakukan penelitian terkait interaksi obat PGK di RSUD Prof. Dr. W. Z. Johannes sehingga data deskriptif seperti ini sangat dibutuhkan. Penelitian ini bertujuan untuk menggambarkan interaksi obat PGK di RSUD Prof. Dr. W. Z. Johannes tahun 2018.

\section{Metode}

\subsection{Desain penelitian}

Penelitian ini merupakan penelitian deskriptif observasional (non eksperimental). Pendekatan pengumpulan data yang digunakan adalah pendekatan retrospektif, dengan melihat data rekam medis. Penelitian ini telah mendapat persetujuan dari pihak RSUD Prof. Dr. W. Z. Johannes Kupang yang ditandai dengan telah disetujuinya surat ijin penelitian oleh pihak rumah sakit (No. SK: 344/DIKLAT/VII/2019).

\subsection{Populasi dan sampel}

Karakteristik populasi penelitian ini adalah data RM pasien PGK yang menjalani rawat inap di RSUD Prof. Dr. W. Z. Johannes Kupang sepanjang tahun 2018, yang berjumlah $400(\mathrm{~N})$. Jumlah sampel (n) ditentukan berdasarkan ukuran sampel minimum yang dianjurkan oleh Fraenkel dan Wallen untuk penelitian deskriptif yaitu 100, dengan menggunakan teknik systematic sampling [6]. Sampel dipilih dengan rentang interval (k) 4. Sebanyak 16 sampel dieksklusi karena data rekam medis yang tidak lengkap, sehingga jumlah sampel yang dianalisis selanjutnya sebanyak 84 .

\subsection{Analisis data}


Instrumen penelitian yang digunakan adalah tools drugs interaction checker yang diakses dari situs drugs.com. Data penelitian yang tercatat pada lembar pengumpul data dianalisis untuk masing-masing pasien dengan menginput semua nama kandungan aktif obat yang diberikan pada pasien tersebut, yang selanjutnya akan dikelompokkan oleh sistem menjadi pasanganpasangan obat (tiap pasang terdiri dari 2 kandungan aktif).

Data dianalisis secara deskriptif kuantitatif dengan menggambarkan secara akurat dan sistematis (mengukur) interaksi obat potensial (yang secara teori berpotensi terjadi namun belum ada manifestasi secara klinis), yang didapatkan dari identifikasi oleh tools drugs interaction checker. Tools ini menyajikan hasil bagi pasien atau masyarakat awam (dengan bahasa awam dan pemahaman yang sederhana) dan tenaga kesehatan profesional. Selanjutnya dipilih penyajian untuk tenaga kesehatan profesional, yang mana analisis interaksi obat dipaparkan berdasarkan tingkat keparahan, halhal yang perlu dimonitoring, manajemen klinis yang disarankan, serta referensi yang digunakan. Basis data pada analisis interaksi obat disediakan oleh "Cerner Multum". Tingkat keparahan interaksi obat diklasifikasikan menjadi ringan, sedang, dan berat. Interaksi berat mempunyai signifikansi klinis yang tinggi, sehingga kombinasi obat tersebut harus dihindari karena risiko jauh lebih besar dari manfaat. Interaksi sedang mempunyai signifikansi klinis yang sedang, yang mana umumnya jika dapat, kombinasi obat dihindari, namun dapat digunakan bersama untuk beberapa kondisi khusus. Interaksi ringan menunjukkan signifikansi klinis yang rendah, yang mana risiko relatif kecil, dapat dipilih alternatif terapi atau dilanjutkan terapi dengan melakukan pemantauan. Hasil analisis data kemudian disajikan dalam bentuk tabel dan diagram batang.

\section{Hasil dan pembahasan}

\subsection{Demografi pasien}

Demografi pasien yang disajikan dalam penelitian ini menampilkan data jenis kelamin dan usia. Pada jenis kelamin, jumlah pasien wanita sebanyak 65,5\% lebih banyak dari pasien pria (Gambar 1a). Penelitian Adibe et al. (2017) menunjukkan hasil yang serupa, dengan persentase pasien wanita sebesar 52,1\% [5], sedangkan penelitian Marquito menunjukkan hasil yang berbeda, dengan persentase pasien PGK laki-laki sebesar 54,7\% [3].

Prevalensi PGK cenderung lebih tinggi pada perempuan, meskipun keparahan penyakit lebih tinggi pada laki-laki yang juga mempunyai prevalensi tinggi pada Penyakit Ginjal Tahap Akhir (End Stage Renal Disease/ESRD). Hormon seksual pada perempuan (estrogen dan progesteron) diduga mempunyai peran utama pada mekanisme biologis terkait variabilitas prevalensi PGK antara laki-laki dan perempuan [7]. Sebuah kajian tematik oleh Neugarten dan Golestaneh dari Mayo Clinic (2019) menunjukkan interaksi yang kompleks antara faktor biologis dengan pengaruh budaya serta sosioekonomi pada hubungan jenis kelamin dengan PGK. Namun, data-data yang tersedia menunjukkan bahwa perkembangan penyakit ginjal lebih cepat pada laki-laki (yang menyebabkan prevalensi ESRD yang lebih tinggi pada laki-laki) dibandingkan perempuan, yang disebabkan oleh pengaruh hormon seksual [8].

Kelompok usia pasien lanjut usia (lansia) dikelompokkan berdasarkan klasifikasi Kementerian Kesehatan (Kemenkes), yaitu lansia awal (46-55 tahun), lansia akhir (56-65 tahun), dan manula (> 65 tahun), dengan persentase paling tinggi $67,9 \%$ pada usia 46-55 tahun (Gambar 1b). Prevalensi PGK meningkat secara dramatis seiring bertambahnya usia. Hal ini berkaitan dengan adanya berbagai faktor risiko PGK, seperti hipertensi dan diabetes melitus yang dialami pasien. Selain itu juga diakibatkan oleh penurunan fungsi ginjal seiring peningkatan usia. Penelitian Baltimore Longitudinal Study of Aging (BLSA) menunjukkan bahwa fungsi ginjal 
menurun pada individu dengan peningkatan usia, dengan rata-rata penurunan klirens kreatinin per tahun sebesar $0,75 \mathrm{ml} /$ menit meski tidak memiliki komorbid [9].

Penelitian ini menunjukkan hasil yang berbeda, yang mana pasien PGK lansia pada kelompok yang lebih muda (lansia awal) lebih banyak dibandingkan manula. Penelitian evaluasi dan manajemen terapi oleh Mallapallil et al. menunjukkan prevalensi diabetes melitus dan penyakit kardiovaskuler yang berkembang menjadi PGK menyebabkan meningkatnya prevalensi PGK pada usia di bawah 60 tahun [10].

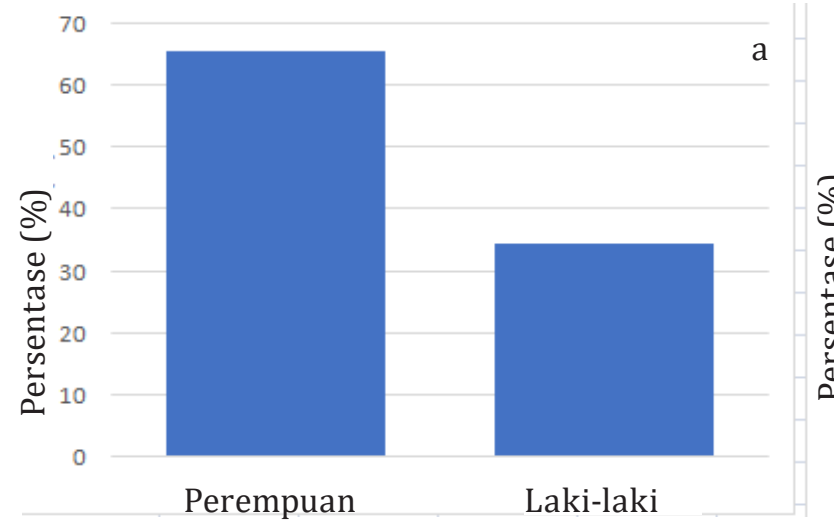

tersebut yang mendasari pemilihan terapi pada pasien PGK. Paradigma renoproteksi dengan Angiotensin-Converting Enzyme inhibitor (ACEI) dan/atau Angiotensin II Receptor Blockers (ARB) guna menurunkan proteinuria dan menunda progresi PGK disarankan diberikan secara kombinasi karena memberikan manfaat yang lebih baik dibandingkan terapi tunggal. Di sisi lain, penggunaan kombinasi ini membutuhkan monitoring pada tekanan darah serta fungsi jantung dan ginjal secara teratur karena dapat meningkatkan risiko kejadian yang tidak dikehendaki, seperti hiperkalemia, Acute Kidney Injury(AKI), dan kondisi lainnyayangharus segera

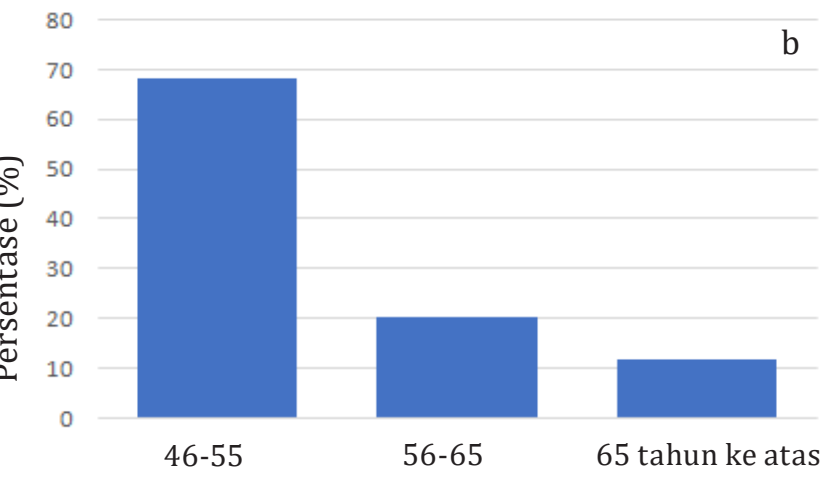

Gambar 1. Distribusi jenis kelamin pasien PGK (a) dan usia pasien PGK (b)

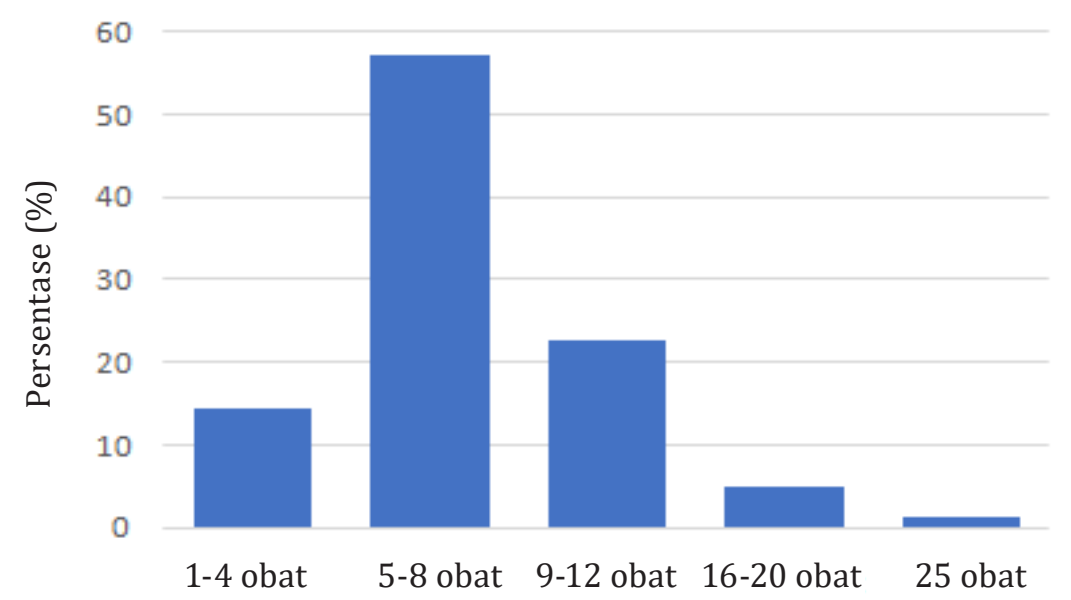

Gambar 2. Jumlah obat pasien PGK selama rawat inap

\subsection{Pola penggunaan obat}

Penyakit komorbid dan penyakit yang mendasari terjadinya PGK dikelompokkan ke dalam non-diabetes (hipertensi, penyakit ginjal polikistik, penyakit glomerular, tubulo-interstitial disease) dan diabetes melitus [11]. Penyakit diterapi sehingga berdampak pada meningkatnya jumlah obat yang digunakan pasien [12].

Jenis obat yang dimaksud dalam penelitian ini adalah golongan obat yang ditujukan untuk mengatasi penyakit penyulit maupun komplikasi, yang mana dalam penelitian ini terdapat 18 
Tabel 1. Distribusi jenis obat yang diberikan pada pasien PGK

\begin{tabular}{ll}
\hline Jenis obat & Frekuensi diresepkan \\
\hline Kardiovaskuler-antihipertensi & 247 \\
Suplemen & 135 \\
\hline Gastrointestinal & 77 \\
\hline Antibiotik & 28 \\
\hline Antigout & 10 \\
\hline Antihistamin & 4 \\
\hline Antiansietas & 6 \\
\hline Analgesik anti inflamasi & 21 \\
\hline Antihemolitik & 3 \\
\hline Saluran pernapasan & 10 \\
\hline Anti diabetes & 5 \\
\hline Obat anti tuberculosis & 1 \\
\hline Antidiare & 5 \\
\hline Antikonstipasi & 3 \\
\hline Antiretroviral & 2 \\
\hline Antifungi & 1 \\
\hline Antikonvulsan & 1 \\
\hline Antikoagulan & 8 \\
\hline
\end{tabular}

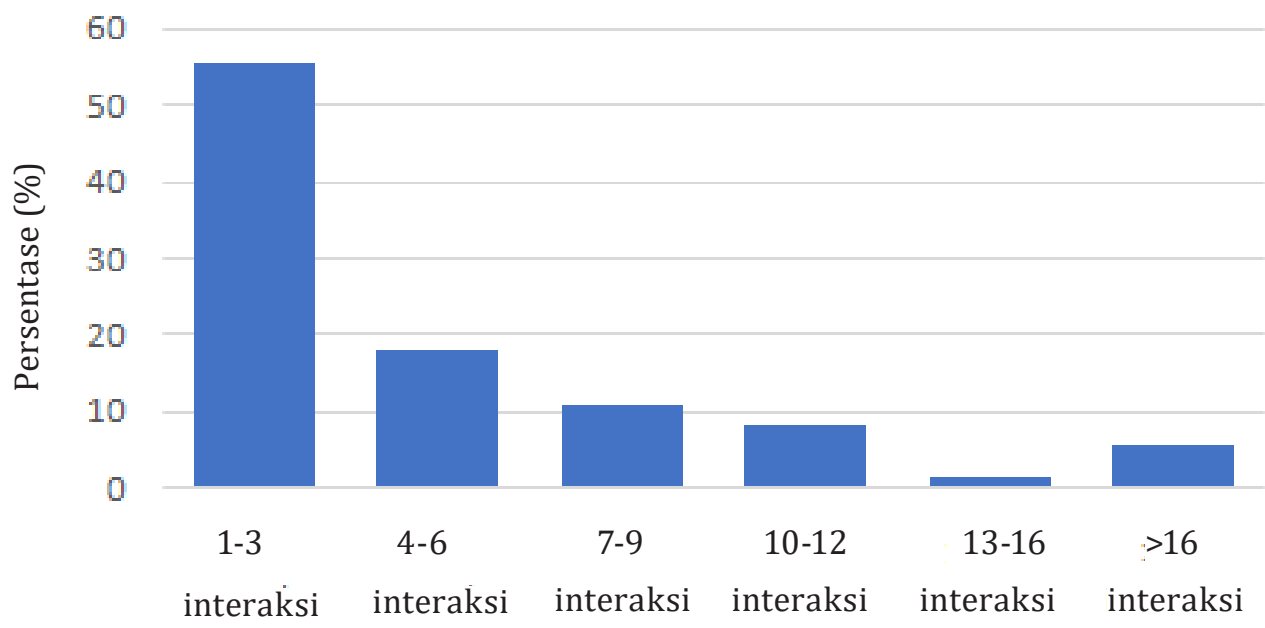

Gambar 3. Distribusi interaksi obat pada pasien PGK

jenis obat (Tabel 1). Terapi farmakologi PGK berfokus pada pengobatan penyakit penyulit yang diderita oleh pasien, atau dengan kata lain penyakit PGK tidak memiliki lini terapi khusus [13]. Berdasarkan hasil penelitian ini, jenis obat terbanyak yang diberikan merupakan golongan kardiovaskuler-antihipertensi (sebanyak 247 peresepan). Kondisi PGK dapat merupakan komplikasi dari hipertensi yang tidak terkontrol.
Sebaliknya, PGK juga mengakibatkan hipertensi karena terjadinya retensi natrium (pada kondisi normal, saat tekanan darah meningkat, natrium akan segera diekskresikan keluar tubuh bersama air; namun pada pasien PGK hal ini tidak terjadi akibat penurunan fungsi ginjal) yang selanjutnya berdampak pada peningkatan volume darah intravaskular secara terus-menerus. Kondisi inilah yang menyebabkan adanya peningkatan 


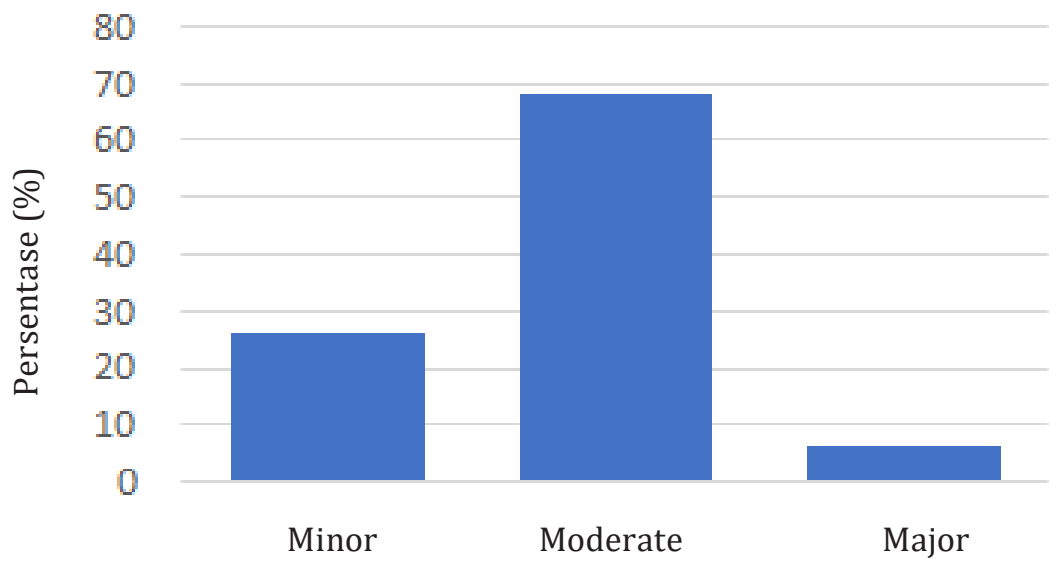

Gambar 4. Distribusi interaksi obat berdasarkan tingkat keparahan

tekanan darah. Pemberian obat-obatan ini bertujuan untuk mengontrol tekanan darah pasien PGK [14].

Jumlah obat dalam penelitian ini didefinisikan sebagai total seluruh jenis obat yang diresepkan pada pasien PGK selama menjalani rawat inap, baik itu obat untuk mengatasi penyakit penyulit maupun komplikasi. Jumlah obat rata-rata yang paling sering diresepkan selama pasien PGK dirawat inap adalah 5-8 obat $(57,1 \%)$ yang diterima oleh 47 pasien (Gambar 2).

Pemberian obat didasarkan pada beberapa alasan, seperti pertimbangan antara benefit-risk yang dihasilkan dari terapi, penyesuaian dosis/ dosage adjustment (terutama untukpasien dengan kondisi khusus, misalnya PGK), penyesuaian dengan kebutuhan pasien, penggunaan obat yang paling dikenal dan telah teruji klinis, serta pemilihan cara pemberian obat yang paling aman. Akibatnya dengan jenis penyakit penyulit yang sama, pasien bisa mendapatkan terapi obat yang berbeda [12].

\subsection{Interaksi obat}

Analisis interaksi obat dilakukan dengan penelusuran pada bank data dari situs drugs. com yang mana data interaksi obat potensial selanjutnya dikelompokkan berdasarkan tingkat keparahannya, yaitu ringan, sedang, dan berat. Didapatkan terapi obat 72 pasien $(85,7 \%)$ menunjukkan interaksi obat potensial, sementara
12 pasien $(14,3 \%)$ lainnya tidak.

Terapi obat pada 40 pasien $(55,6 \%)$ dalam penelitian ini menunjukkan 1-3 interaksi obat potensial, pada 13 pasien $(18,06 \%)$ menunjukkan 4-6 interaksi obat potensial, pada 8 pasien (11,11\%) menunjukkan 7-9 interaksi obat potensial, pada 6 pasien $(8,33 \%)$ menunjukkan 10-12 interaksi obat potensial, pada 1 pasien (1,39\%) menunjukkan 13 interaksi obat potensial, serta pada 4 pasien $(5,56 \%)$ menunjukkan $>16$ interaksi obat potensial (Gambar 3).

Penelitian Olumuyiwa et al. (2017) menghasilkan bahwa prevalensi polifarmasi pada pasien PGK sebesar 85,37\% dan prevalensi kejadian interaksi obat sebesar 70,54\% [15]. Temuan ini semakin memperkuat hasil yang diperoleh dalam penelitian ini, yaitu peluang interaksi obat potensial berbanding lurus dengan jumlah obat yang diresepkan.

Interaksi obat potensial pada penelitian ini, selanjutnya dikelompokkan berdasarkan tingkat keparahannya (Gambar 4). Diperoleh hasil tingkat keparahan ringan (minor) sebesar 26\%, tingkat keparahan sedang (moderate) sebesar 68\%, dan tingkat keparahan berat (major) sebesar 6\%. Berdasarkan data yang diperoleh ditemukan bahwa interaksi obat terbanyak adalah interaksi obat dengan tingkat keparahan sedang (68\%). Pada tingkat keparahan sedang dibutuhkan penyesuaian dosis (dose adjustment) dari obatobat yang berpotensi menyebabkan interaksi 


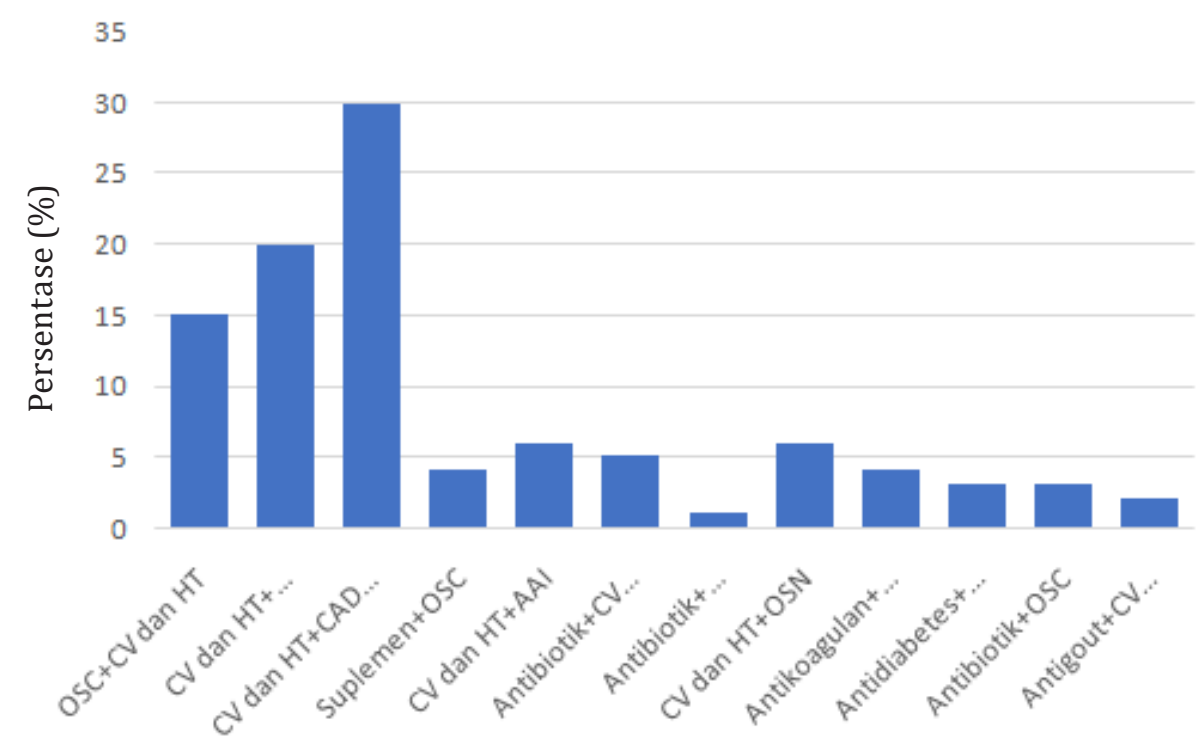

Gambar 5. Jenis obat yang paling sering berinteraksi pada pasien PGK

atau dilakukan pemantauan, baik gejala klinis maupun nilai/marker pemeriksaan laboratorium oleh praktisi kesehatan yang merawat pasien.

Interaksi obat dengan insidensi tertinggi dari penelitian ini adalah antara sesama obat kardiovaskuler-antihipertensi, yang mana terdapat $30 \%$ yang berinteraksi, disusul interaksi antara obat kardiovaskuler-antihipertensi dengan suplemen sebanyak 20\%, dan interaksi antara obat kardiovaskuler-antihipertensi dengan obat saluran cerna sebanyak 15\% (Gambar 5). Sebagaimana dipaparkan pada hasil sebelumnya bahwa obat kardiovaskular-antihipertensi merupakan golongan obat yang paling banyak diresepkan pada pasien, sehingga meningkatkan risiko interaksi obat potensial dengan sesama obat kardiovaskular-antihipertensi dan dengan obat golongan lain.

Pasien dengan PGK memiliki risiko tinggi mengalami gangguan kardiovaskular dan sebaliknya, karena itu menerima banyak peresepan obat (polifarmasi). Hasil yang serupa juga terlihat pada penelitian Becquemont et al. bahwa golongan obat yang paling sering berinteraksi merupakan golongan obat kardiovaskular-antihipertensi, yaitu diuretik loop, penghambat RAS (ACEI dan ARB), dan CCB (Calcium Channel Blocker) [16].

Manifestasi klinis dari interaksi antara sesama obat kardiovaskular-antihipertensi adalah peningkatan efek hipotensif (penurunan tekanan darah yang berlebih dari seharusnya), sehingga perlu dimonitoring pemeriksaan tekanan darah pasien, yang mana pada penelitian ini belum terjadi secara aktual karena tekanan darah pasien tidak ada yang terlalu rendah dan gejala klinis tidak tercatat pada rekam medis. Efek aditif dari interaksi ini umumnya bermanfaat secara klinis, meskipun gejala hipotensi dosis pertama (first dose hypotension), seperti pusing, pucat, lemas, atau pingsan dapat muncul. Sebagian kecil efek dari interaksi antara sesama obat kardiovaskularantihipertensi menghambat penurunan tekanan darah sehingga perlu dimonitoring secara khusus.

Manifestasi klinis akibat interaksi golongan obat kardiovaskuler-antihipertensi dengan suplemen adalah penurunan efek farmakologi obat kardiovaskuler-antihipertensi oleh suplemen kalsium. Efek ini juga merupakan manifestasi klinis yang paling umum dari interaksi obat kardiovaskuler-antihipertensi dengan obat saluran cerna. Pada penelitian ini, manifestasi klinis dari kedua interaksi obat ini telah terjadi secara aktual. Terlihat data tekanan darah pasien pada rekam medis rata-rata belum mencapai target terapi (target pada pasien PGK $<$ 140/90 mmHg), atau dengan kata lain pasien mengalami hipertensi resisten [15]. Berkaitan 
dengan penurunan tekanan darah maupun peningkatan darah sebagai efek dari interaksi obat kardiovaskular-antihipertensi, penggunaan 24-hour Ambulatory BP Monitoring (ABPM) untuk memantau secara lebih efektif tekanan darah dan menjadi prediktor kejadian kardiovaskular pada pasien PGK dibandingkan pemantauan gejala klinis [17].

Manifestasi klinis dari interaksi obat dengan tingkat keparahan ringan tidak terjadi. Tetapi di sisi lain, temuan dalam penelitian ini menunjukkan bahwa ada interaksi obat dengan tingkat keparahan berat, yaitu antara simvastatin dan amlodipin, meski jumlahnya kurang dari 10\% (6\%), yang mana manifestasi klinis dari interaksi ini dapat mengancam jiwa pasien sehingga harus segera ditangani. Induktor dan inhibitor dari CYP-450 isoenzim merupakan penyebab dari interaksi obat golongan statin. Pada penggunaan dengan amlodipin, terjadi inhibisi metabolisme simvastatin pada CYP450 3A4 di liver yang menyebabkan peningkatan risiko rhabdomiolisis [18].

Penelitian The Study of Heart and Renal Protection (SHARP) menunjukkan 17\% penurunan kejadian aterosklerosis mayor dan 25\% kejadian stroke non-hemoragik dari penggunaan simvastatin $20 \mathrm{mg}$ dengan ezetimib pada 9270 pasien PGK sedang hingga berat [19]. Meskipun demikian risiko rhabdomiolisis akibat penggunaan bersama dengan amlodipin harus diperhatikan mengingat dapat mengancam jiwa akibat nekrosis sel otot yang sangat besar, termasuk hiperkalemia dan hipokalemia yang membahayakan pada pasien dengan gangguan ginjal, termasuk PGK. Pada bentuk rhabdomiolisis yang paling parah, laju mortalitas pasien dapat meningkat hingga 59\% [20]. Oleh karena itu, Borges et al. menyimpulkan pada penelitiannya untuk menggunakan atorvastatin pada pasien PGK yang juga menggunakan amlodipine dengan tingkat keparahan interaksi sedang dan dapat dilakukan pemantauan [18].

Berdasarkan penelitian ini diketahui bahwa pasien PGK RSUD Prof. Dr. W. Z. Johannes berpeluang mengalami interaksi obat yang berdampak pada berbagai tingkat keparahan (berdasarkan data pada Gambar 4). Oleh karena itu perlu diberikan perhatian khusus dan pemantauan terhadap penggunaan obat-obatan pada pasien PGK di RSUD Prof. Dr. W. Z. Johannes.

\section{Kesimpulan}

Penelitian ini menyimpulkan bahwa sebanyak 72 pasien $(85,7 \%)$ memiliki potensi interaksi obat dengan jumlah interaksi obat terbanyak, yaitu 1-3 interaksi obat, yang terjadi pada 40 pasien $(55,6 \%)$. Tingkat keparahan interaksi obat sedang merupakan yang paling tinggi $(68,0 \%)$.

\section{Keterbatasan Penelitian}

Penelitian ini menggunakan teknik systematic sampling, yang mana dari 400 populasi hanya diambil 100 sampel dan 16 sampel dieksklusi. Kelebihan sampel ini adalah sampel diacak secara sistematis sehingga semua anggota populasi memiliki kesempatan yang sama menjadi sampel, sedangkan kekurangannya adalah kasus klinis pada data populasi yang tidak menjadi sampel belum tentu diwakili oleh sampel yang diambil secara acak, mengingat lebih banyak data yang tidak diambil.

\section{Ucapan Terima Kasih}

Penulis mengucapkan terimakasih kepada Universitas Citra Bangsa Kupang sebagai institusi asal peneliti, Yayasan Archipelago Scholar atas bantuan dana publikasi penelitian, dan pihak RSUD Prof. Dr. W. Z. Johannes yang telah membantu dalam pengambilan data penelitian.

\section{Daftar Pustaka}


1. Inker LA, Astor BC, Fox CH, et al. KDOQI US commentary on the 2012 KDIGO clinical practice guideline for the evaluation and management of CKD. Am J Kidney Dis. 2014;63(5):713-35.

2. Cascorbi I. Arzneimittelinteraktionen: Prinzipien, Beispiele und klinische Folgen. Dtsch Arztebl Int. 2012;109(33-34):546-56.

3. Marquito AB, Fernandes NM, Colugnati FA, Paula RB. Identifying potential drug interactions in chronic kidney disease patients. Brazilian Journal of Nephrology. 2014;36(1):26-34.

4. Widyati D. Praktik Farmasi Klinik. Uwais Inspirasi Indonesia; 2019.

5. Adibe MO, Ewelum PC, Amorha KC. Evaluation of drug-drug interactions among patients with chronic kidney disease in a South-Eastern Nigeria tertiary hospital: A retrospective study. Pan Afr Med J. 2017;28:1-8.

6. Fraenkel JR, Wallen NE, Hyun HH. How to design and evaluate research in education. New York: McGraw-hill; 2009.

7. Goldberg I, Krause I. the Role of Gender in Chronic Kidney Disease. Cit EMJ. 2016;1(2):58-64.

8. Neugarten J, Golestaneh L. Influence of Sex on the Progression of Chronic Kidney Disease. Mayo Clin Proc. 2019;94(7):1339-56.

9. Prakash S, O'Hare AM. Interaction of Aging and Chronic Kidney Disease. Semin Nephrol. 2009;29(5):497-503.

10. Mallappallil M, Friedman EA, Delano BG, Mcfarlane SI, Salifu MO. Chronic kidney disease in the elderly: Evaluation and management. Clin Pract. 2014;11(5):525-35.

11. Onyedikachi EA, Ogochukwu AM, Chinwendu AK. Evaluation of Drug-Drug Interactions Among Chronic Kidney Disease Patients of Nephrology Unit in the University of Nigeria Teaching Hospital, Ituku-Ozalla, Enugu State. J Basic Clin
Pharm. 2017;8(0):49-53.

12. Zhong J, Yang HC, Fogo AB. A perspective on chronic kidney disease progression. Am J Physiol - Ren Physiol. 2017;312(3):F375-84.

13. Taler SJ, Agarwal R, Bakris GL, et al. KDOQI US commentary on the 2012 KDIGO clinical practice guideline for management of blood pressure in CKD. Am J Kidney Dis. 2013;62(2):201-13.

14. Soi V, Yee J.Sodium Homeostasis in Chronic Kidney Disease. Adv Chronic Kidney Dis. 2017;24(5):32531.

15. Fasipe OJ, Akhideno PE, Nwaiwu O, Adelosoye AA. Assessment of prescribed medications and pattern of distribution for potential drug-drug interactions among chronic kidney disease patients attending the nephrology clinic of lagos university teaching hospital in sub-saharan West Africa. Clin Pharmacol Adv Appl. 2017;9:125-32.

16. Becquemont L, Bauduceau B, Benattar-Zibi L, et al. Association between Cardiovascular Drugs and Chronic Kidney Disease in Non-Institutionalized Elderly Patients. Basic Clin Pharmacol Toxicol. 2015;117(2):137-43.

17. Pugh D, Gallacher PJ, Dhaun N. Management of Hypertension in Chronic Kidney Disease. Drugs. 2019;79(4):365-79.

18. Borges Rde P, Degobi NAH, Bertoluci MC. Choosing statins: A review to guide clinical practice. Arch Endocrinol Metab. 2020;64(6):639-53.

19. Baigent C, Landray MJ, Reith C, et al. The effects of lowering LDL cholesterol with simvastatin plus ezetimibe in patients with chronic kidney disease (Study of Heart and Renal Protection): A randomised placebo-controlled trial. Lancet. 2011;377(9784):2181-92.

20. Candela N, Silva S, Georges B, et al. Short- and long-term renal outcomes following severe rhabdomyolysis: a French multicenter retrospective study of 387 patients. Ann Intensive Care. 2020;10(1):1-7. 